DOI 10.31558/2519-2949.2021.2.8

УДК 352.072.1(477)(076)

ORCID ID: https://orcid.org/0000-0003-3922-7619

Чальцева О. М., Донецький національний університет імені Василя Стуса

ORCID ID: https://orcid.org/0000-0002-2942-7003

Ясько О. Г., м. Вінниця

\title{
ДЕЦЕНТРАЛІЗАЦЯ ЯК ФАКТОР ЕФЕКТИВНОСТІ ДЕРЖАВНОГО УПРАВЛІННЯ НА ПРИКЛАДІ ШВЕЙЦАРІЇ ТА БЕЛЬГІЇ
}

Проаналізовано вплив процесу децентралізаџї на ефективність державного управління на прикладі Швейцарії та Бельгії. У ретроспективній площині описана роль та місие децентралізованого характеру влади, розглянуто переваги та недоліки прочесу децентралізаиії. За допомогою методу кейс-стаді було виявлено відмінності у характері впливу децентралізаџіі публічної влади на демократизацію різних типів політичних систем. Застосовується метод компаративного аналізу динаміки децентралізаџії демократичних федеративних систем, в тому числі методами крос-темпорального та лонгітюдного аналізу, бінарного порівняння. Країни для порівняльного аналізу відбиралися за принципом схожості систем. В результаті були виявлені загальні і особливі політичні характеристики двох моделей децентралізованих державних устроїв в Швейцарії та Бельгії.

Децентралізований характер влади є важливим принципом функиіонування ефективного управління, проте, в рамках різних теорій державного управління важливість децентралізованості є відмінною. Різниться також пояснювальний механізм важливості децентралізації. Так, відповідно до Good Governance, децентралізаџія є способом наближення публічної влади та владних повноважень до громадян, уникнення явища політичного відчуження, активізації політичної участі, оскільки інструменти прямої демократії, які мають корелящію в основних принципах Gооd Governance можуть функиіонувати найкращим чином в невеликих територіальних одиницях місиевого рівня. Таким чином, відповідно до положень ключових теорій державного управління децентралізаиія може стати фактором ефективного врядування, оскільки є одним із принципів функиіонування демократії.

Децентралізачія - ие не розділення країни, ие створення можливостей для розвитку міст, сіл, селищ, там де живуть люди в єдиній Украйні. Це створення умов, де громади зможуть активно залучатися до прочесу прийняття рішень, ие вивільнення енергії мас для покращення свого життя та життя своєї громади, а не створення додаткового прошарку регіональних політичних еліт.

Ключові слова: децентралізачія, федералізм, державне управління, демократія, місиеве самоврядування.

Постановка проблеми. Децентралізація влади в останні десятиліття стала поширеною практикою реформування системи державного управління та місцевого самоврядування. Її визнання на міжнародному рівні підтверджується підтримкою Міжнародним валютним фондом та Світовим банком проєктів, спрямованих на підтримку децентралізаційних ініціатив. Стосовно причин такої політики, то поряд із факторами економічної, фіскальної ефективності, демократизацією політичних режимів, чільне місце посідає потреба в ефективності державного управління. Децентралізація розглядається як механізм наближення влади до громадян, стимулювання політичної участі, а також відповідальності та підзвітності влади на місцевому рівні.

Децентралізований характер влади $є$ важливим принципом функціонування ефективного управління, проте, в рамках різних теорій державного управління важливість децентралізованості $€$ відмінною. Різниться також пояснювальний механізм важливості децентралізації. Так, відповідно до Good Governance, децентралізація є способом наближення публічної влади та владних повноважень до громадян, уникнення явища політичного відчуження, активізації політичної участі, оскільки інструменти прямої демократії, які мають кореляцію в основних принципах Good Governance можуть 
функціонувати найкращим чином в невеликих територіальних одиницях місцевого рівня [1]. Таким чином, відповідно до положень ключових теорій державного управління децентралізація може стати фактором ефективного врядування, оскільки є одним із принципів функціонування демократії.

Проблеми територіальної цілісності і ефективності політичної системи $є$ важливими для будьякої сучасної держави, де Україна не є виключенням. Це питання є дуже актуальним для держави, яка перебуває в процесі реформування своєї політичної системи і потребує створення чіткої системи організації влади, гармонізації відносин між різними ії рівнями та елементами з урахуванням процесів саморегуляції і саморозвитку. Ідея самоорганізації суспільства у формі місцевого самоврядування стала фундаментом нового розуміння політичної складової реформи децентралізації. В рамках області, регіону чи територіальної громади найкращим чином реалізується просторова форма демократії і водночас забезпечуються умови для запровадження сучасних інноваційних моделей розвитку. Але можливість переведення політичної площини децентралізації в режим дезінтеграції чи деградації також не виключена, а зайва політизація міжрегіональних відмінностей здатна посилювати цю тенденцію. В умовах пошуку механізмів, норм та інститутів, здатних пом'якшити імовірні конфлікти і нівелювати протиріччя між центральною владою і регіонами, надзвичайно важливо дослідити процес впровадження реформи децентралізації в Україні та особливу увагу приділити прямому бінарному методу компаративного аналізу зарубіжного досвіду проведення адміністративно-територіальної реформи (Швейцарії та Бельгії) для пошуку найоптимальнішої форми децентралізації, проблем, викликів та потенційних наслідків, що можуть виникнути в процесі іiі впровадження. На наш погляд ці дві країни дуже подібні до України за своєю політичною, економічною та, що важливо, суспільною фрагментарністю. Вони не є гомогенними за багатьма ознаками: теж переживають мовний, етнічний, національний та культурний розкол. Але поміж 3 тим реформа децентралізації не розширила прірву, а, місцями, навпаки - стала мобілізуючим елементом, що об’єднала країни у багатьох сферах. [2]

Аналіз досліджень і публікацій по темі.Серед вітчизняних учених теорію та практику процесу децентралізації влади в контексті науки державного управління досліджували В. Б. Авер'янов, І. А.Грицяк, В. М. Кампо, А. Ф. Колодій, Н. Р. Нижник, А. Ф. Ткачук, В. М.Шаповал та ін. Проте питання співвідношення та взаємодії принципів децентралізації та належного врядування у світлі євроінтеграційних намірів України все ще потребує додаткового вивчення. Науковці зробили чимало теоретичних та емпіричних досліджень, які базувались на кейс-стаді політики децентралізації в окремій країні або у групі країн певного регіону. Попри значну цінність таких емпіричних досліджень, вони все ж не мають характеру аналізу впливу децентралізації на ефективність державного управління у глобальному контексті. Крім того, більшість із цих досліджень зосереджується на використанні якісних, а не кількісних методів досліджень. Тому для визначення дієвості децентралізації як фактору ефективності державного управління ми поєднали якісні та кількісні методи дослідження.

Виклад основного матеріалу. Децентралізація являє собою складний інтегральний соціальний експеримент, який складається з багатьох аспектів: економічного, правового та політичного [3]. В роботі мова йде саме про політичну складову децентралізації для дослідження якої булі виділені основні індикатори (критерії) порівняння. Якщо ми виокремлюємо політичну складову від загальної децентралізації, тому і індикатори порівняння в складних децентралізованих політичних системах слід брати, спираючись на політичні критерії децентралізації.

Перший індикатор - ефективність управління, який базується на світових показниках управління (Worldwide Governance Indicators) [4]. Індекс складається з 6 підіндексів: врахування думки населення і підзвітність державних органів, політичної стабільність і відсутність насильства, ефективності роботи уряду, якості законодавства, верховенства закону, контролю над корупцією.

Показник нестабільності країн $є$ наступним індикатором. Це комплексний показник, який спирається на Індекс недієздатності держав, що характеризує здатність (і нездатність) влади тієї або іншої країни контролювати цілісність своєї території, а також демонструє демографічну, політичну і економічну ситуацію в країні. Індекс нестабільних держав [5] складається з багатьох складових, але особливу увагу було приділено такому компоненту як “Розколотість політичної еліти".

Третій і останній індикатор дослідження -показник розвитку демократії. Індекс розвитку демократії (Democracy index) [6]. Індекс складається з п'яти основних компонентів: виборчий процес і плюралізм, діяльність уряду, політична участь, політична культура та громадянські свободи.

Традиційні федерації (США, Німеччина, Австралія, Австрія, Швейцарія) в останні десятиліття піддалися різним модифікаціям, часто серйозним, тому можна стверджувати про перехід частини 
3 них від одного федерального типу до іншого. Частина унітарних держав піддалася викликам, як з боку глобалізації міжнародних відносин, так і з боку локальних внутрішніх політичних процесів. Такі держави, як Швейцарія та Бельгія відповіли на це або серйозними процесами децентралізації влади, або формуванням федеральних державних устроїв.

В останні десятиліття деякі країни перейшли до більш децентралізованої державної структури. Це призвело до збільшення повноважень щодо прийняття рішень на субнаціональних рівнях. I хоча перехід до децентралізації в процесі прийняття рішень має місце у всьому світі, але уперше це відбулося саме в Європі. Це можна пояснити з історичного ракурсу: кордони європейських країн постійно змінювалися на протязі всієї історії. Великі імперії розпадалися на цілий ряд нових незалежних утворень з іншими формами політичної самоорганізації. Боротьба людей у досягненні автономії в прийнятті рішень мають місце як кривавих сценаріїв (Північної Ірландії) так і відносно мирних (Каталонія). Потенційним рішенням пристосувати ці вимоги - $\epsilon$ будівництво децентралізованих держав. Глибокий компаративний аналіз децентралізації Бельгії та Швейцарії зумовлений тим, що обидві країни є частиною Свропейського Союзу, який інституційно «слабший», ніж традиційні національні держави. I хоча обидві країни подібні за багатьма ознаками, стає цілком очевидним, те, що основна відмінність між ними - протилежність відправних точок і напрямків у федеральній динаміці: в швейцарському випадку, федералізм був відправною точкою внаслідок агрегації раніше незалежних кантонів, в той час як Бельгія починала цей процес як унітарна національна держава.

Антецедентною змінною у нашому дослідженні $\epsilon$ історичні передумови, які сприяли становленню процесів децентралізації в моделях державно-територіального будівництва Швейцарії та Бельгії. На перший погляд Бельгія і Швейцарія досить схожі: обидві маленькі країни (чисельність 11,5 та 8,5 мільйонів), розташовані на перетині декількох великих культурних зон, мають кілька офіційних мов (голландська, французька та німецька мови є офіційними в Бельгії, в той час як Швейцарія надала французькій, німецькій, італійській та ретороманській статус державних).

Незважаючи на малі розміри, ці дві держави $є$ економічно розвинутими. Водночас федеральна динаміка і наслідки цього складного процесу в обох країнах істотно відрізняються. Щодо Бельгії, то до Наполеона, область входила до складу Королівства Бельгія, тоді відомої як Південні Нідерланди. Це був союз автономних феодальних регіонів. Протягом короткого періоду в 1790 відбулась трансформація територіального устрою, було встановлено конфедерацію, яка отримала назву Сполучені Штати Бельгії. Після приходу Наполеона область було включено у Французьку імперію, об'єднавши іiі з Північними Нідерландами. У 1830p., після короткотривалої Бельгійської революції країна виборює незалежність і стає унітарною державою з високим рівнем місцевого самоврядування. Центральній владі були надані тільки законодавчі повноваження. 163 років по тому, в 1993р. Бельгія стає федеративною державою, в рамках четвертої реформи адміністративно-територіального устрою. У 2012-2013 рр. були внесені додаткові правки у чинне законодавство. Отже, перетворення Бельгії на федеративну державу не є результатом злиття різних держав або інших суб'єктів [7]

На відмінну від кейсу Бельгії Швейцарія не запроваджувала місцеве самоврядування після довготривалої централізації, а навпаки - це держава, яка розвивалася «знизу догори», розбудовуючи власну історію децентралізованого врядування. Швейцарія, як держава, сформувалася унаслідок об'єднання різних незалежних політичних одиниць (кантонів) у конфедерацію з метою збереження зовнішньої незалежності та захисту внутрішньої структури влади. Водночас кантони залишалися суверенними та зберігали повноваження у вирішенні більшості питань. Для прийняття рішень, які вимагали співпраці, наприклад, у сфері зовнішньої безпеки, було створено спільну політичну інституцію, подібну до парламенту. Договір між кантонами регулював аспекти спільного прийняття рішень. Єдиний крок у напрямі централізованого врядування Швейцарія зробила під час французької окупації під проводом Наполеона, що тривала з 1798-го по 1815 рік. Це була крайня умова задля збереження цілісності країни. Але внаслідок сильного відцентрового соціально-політичного супротиву вже тоді довелося послабити централізований тип управління. Як тільки французи відступили, Швейцарія повернулася до старих інститутів та старої системи врядування. Французька окупація проте привнесла до Швейцарії й нові ідеї. Різні бачення ролі держави призвели до сутичок між більш прогресивними протестантськими групами і більш консервативними католиками. У нетривалій Громадянській війні 1847 р. консервативні католики зазнали поразки, що відкрило шлях для реформ. У 1848-му було прийнято нову Конституцію. Саме в цей час Швейцарія перетворилася 3 конфедерації на федерацію. Згідно з новою Конституцією 1848 року кантони зберегли міцні позиції. Усі повноваження, які не покладалися на центр, залишалися за кантонами (так звані остаточні 
повноваження). Іншими словами, кантони зберегли право на самоуправління чи самоврядування. Водночас центр отримав додаткові повноваження, зокрема, право встановлювати та стягувати деякі податки. Кантони зберегли можливість впливати на прийняття рішень на рівні центру, наприклад, на основі представництва кантонів у другій палаті парламенту (роздільне управління). Права центру та кантонів були прописані у Конституції. До Конституції Швейцарії часто додавалися нові положення. Більшість з цих додатків полягала у часткових поправках. Утім, у 1874 та 1999 роках Конституція піддавалася повному перегляду, але основні положення щодо політичної системи залишалися завжди незмінними. Тобто інституційно адміністративний устрій Швейцарії залишається подібним до устрою, затвердженого ще в 1848 р. [8].

Світова політична наука розглядає децентралізацію як один 3 ключових елементів усебічної реформи системи державного управління. Децентралізація повноважень і ресурсів може стати чинником підвищення ефективності усього процесу управління, а також істотно посилити його демократичну складову. Це має особливе значення для України, яка переживає складний і суперечливий процес демократичної трансформації після довгих десятиліть жорстко централізованої системи влади і управління під ідеологічним контролем центральної партійнодержавної адміністрації. Тут, необхідно зробити обмовку: децентралізація приносить бажаний результат тільки у тому випадку, якщо сприяє мобілізації громадського потенціалу на рішення соціально значущих проблем, якщо заохочує і посилює процеси участі населення в здійсненні управління на регіональному (в рамках однієї країни) і місцевому рівнях. Інакше, відірвана від громадян і така, що не рахується з їх інтересами, центральна бюрократія заміщується такою ж відірваною від людей, але професійно менш підготовленою провінційною і місцевою бюрократією. Децентралізація, що не веде до більшої відкритості і широкої участі громадян в процесі управління громадськими справами, не може розглядатися як ефективний інструмент збільшення потенціалу державного управління.

Комплекс показників управління (Worldwide Governance Indicators) демонструє основні тенденції та результати розвитку управління в федеративних системах Швейцарії та Бельгії. Показники управління відображають шість основних аспектів інституційної якості або ефективності управління: врахування думки населення, політична стабільність, ефективність влади, якість законодавства, верховенство закону, боротьба з корупцією.

За багатьма показниками державного управління ці дві країни дуже подібні, але існують відмінності на які слід звернути увагу. Політична стабільність і відсутність насильства (Political Stability and Absence of Violence) - показник, на якому ми повинні зробити особливий наголос. Як можна побачити, за останніми даними у Бельгії він значно похитнувся, на відміну від Швейцарії.

Бельгія вже не $\epsilon$ національною державою в будь-якому структурно-функціональному сенсі, а швидше "федерацією" трьох різних регіонів (Фландрія, Валлонія, Великий Брюссель) та трьох різних мовних спільнот (голландська, французька та німецька). В результаті реформи децентралізації роль національної держави була сильно послаблена на користь місцевого самоврядування, а адміністративно-територіальні одиниці не завжди накладаються один на одного географічно, демографічно чи політично. Політична система Бельгії стала уразливішою для внутрішніх та зовнішніх викликів (тероризм, біженці, санкційна політика, суперечки всередині $Є С$ тощо). Водночас Швейцарія, попри мовну, культурну та політичну неоднорідність продемонструвала стійкість своєї політичної системи.

Наступним індикатором $є$ показник нестабільності системи, який базується на Індексі нестабільності країн (Fragile State Index). Це комплексний показник, що характеризує здатність (i нездатність) влади тієї або іншої країни контролювати цілісність своєї території, а також демографічну, політичну і економічну ситуацію в країні. Індекс нестабільності країн враховує показники з різних сфер: соціальної, економічної та політичної. Ми акцентували увагу саме на політичному аспекті в частині розколотості політичної еліти. У Бельгії цей індикатор учетверо вищий ніж у Швейцарії.

"Ліберальна" Фландрія та "соціалістична" Валлонія мають різні бачення подальшого розвитку своєї країни в контексті переосмислення себе як дієздатної національної держави. Майже кожні загальні вибори та подальші переговори коаліційного федерального уряду закінчуються укладанням угоди з передачі ще більших повноважень своїм регіонам, що ще більший провокує розкол політичних еліт. Бельгія вже зараз проживає проміжний етап на шляху передбаченого, але не до кінця усвідомленого політичного розколу. I з кожним роком ця прірва зростає, що $є$ виразним проявом дисфункції загальнонаціональної бельгійської політичної системи. [9] 


\section{Worldwide Governance Indicators}

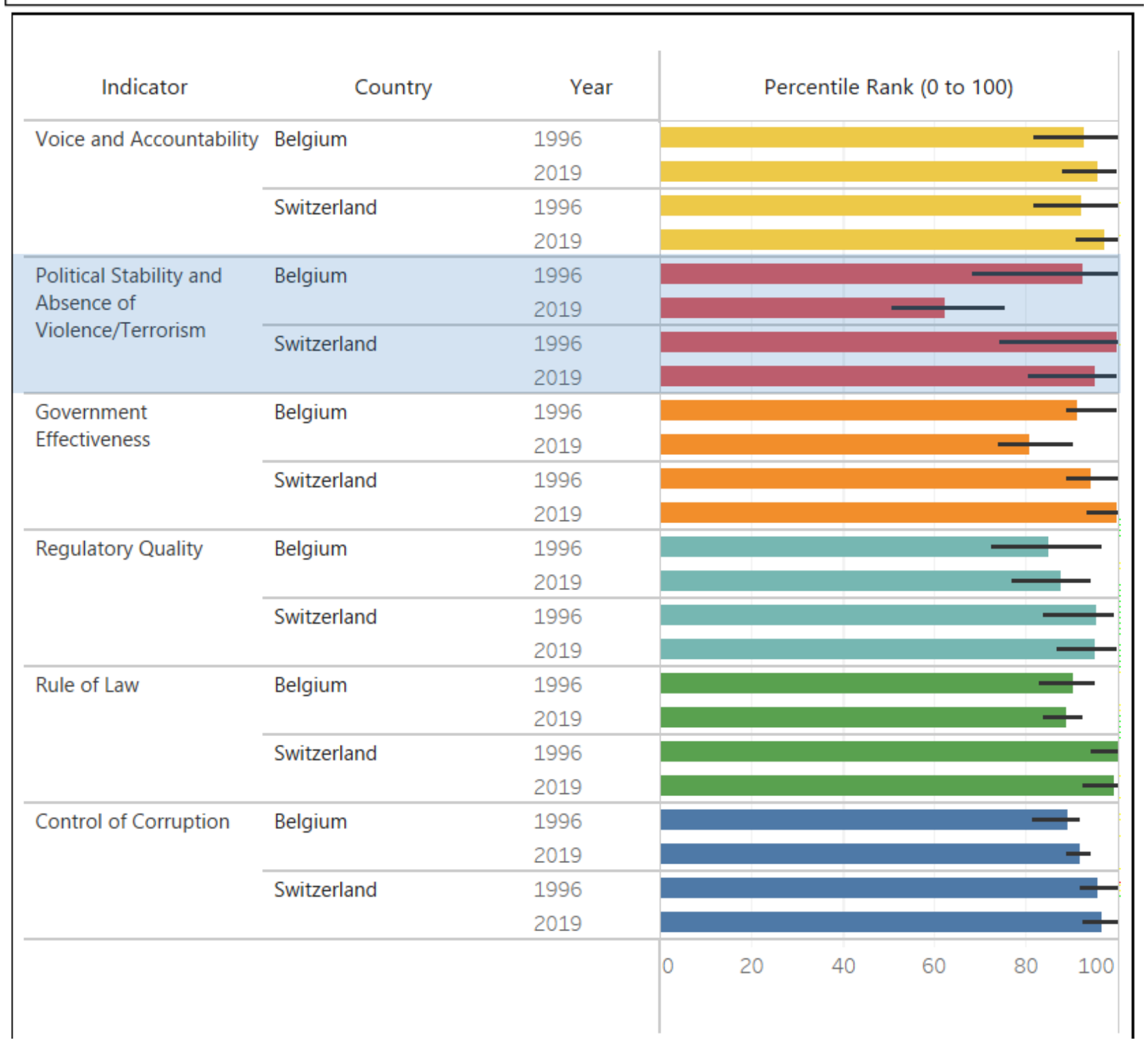

Рис. 1. Значення комплексу показників управління (Worldwide Governance Indicators) для Швейцарії та Бельгіï у 1996 та 2019 рр.

Децентралізація є способом територіальної організації влади, при якому держава передає право на прийняття рішень по визначених питаннях або у визначеній сфері структурам локального або регіонального рівня, що не входять у систему виконавчої влади і $є$ відносно незалежними від неї [10]. Закріплення за органами місцевого самоврядування повноважень здійснюється за принципом, що «завдання, які можна успішно виконувати на найнижчому рівні управління (наприклад, на рівні муніципалітетів), повинні здійснюватися саме там, тоді як за завдання, що є поза межами невеликого муніципалітету, мають відповідати регіональні органи управління».

Децентралізація виступає як одна 3 форм розвитку демократії, що дозволяє, при збереженні держави і ііі інститутів активізувати населення на рішення власних (колективних) потреб і інтересів та зменшити сферу впливу держави на суспільство, заміняючи цей вплив саморегулюючими механізмами, виробленими самим суспільством. Серед українців ще остаточно не сформоване розуміння власної значимості у здійсненні місцевої влади і управління, можливості вираження своїх i колективних інтересів безпосередньо чи через представницькі органи. Саме це є основною перепоною розвитку демократії через інститут місцевого самоврядування. Існування окреслених 
проблем в Україні $є$ наслідком нерозуміння самої природи місцевого самоврядування і визначення його змісту в законодавстві України. Саме тому органи місцевого самоврядування в Україні в процесі децентралізації мають виступати як недержавні центри влади, сприяючи розвитку демократії в країні. Цим зумовлено обрання нами Індексу демократії, як одного з основних критеріїв для компаративного аналізу децентралізаційного процесу в Швейцарії та Бельгії.

Таблиия 1

Значення Індексу демократії для країні Європи в 2020 р.

\begin{tabular}{|c|c|c|c|c|c|c|c|c|c|}
\hline & $\begin{array}{l}\text { Overall } \\
\text { score }\end{array}$ & $\begin{array}{l}\text { Global } \\
\text { Rank }\end{array}$ & $\begin{array}{l}\text { Regional } \\
\text { rank }\end{array}$ & $\begin{array}{l}\text { I Electoral process } \\
\text { and pluralism }\end{array}$ & $\begin{array}{l}\text { II Functioning of } \\
\text { government }\end{array}$ & $\begin{array}{c}\text { III Political } \\
\text { participation }\end{array}$ & $\begin{array}{l}\text { IV Political } \\
\text { culture }\end{array}$ & $\begin{array}{l}\text { VCivil } \\
\text { liberties }\end{array}$ & Regime type \\
\hline Norway & 9.81 & 1 & 1 & 10.00 & 9.64 & 10.00 & 10.00 & 9.41 & Full democracy \\
\hline Iceland & 9.37 & 2 & 2 & 10.00 & 8.57 & 8.89 & 10.00 & 9.41 & Full democracy \\
\hline Sweden & 9.26 & 3 & 3 & 9.58 & 9.29 & 8.33 & 10.00 & 9.12 & Full democracy \\
\hline Finland & 9.20 & 6 & 4 & 10.00 & 8.93 & 8.89 & 8.75 & 9.41 & Full democracy \\
\hline Denmark & 9.15 & 7 & 5 & 10.00 & 8.93 & 8.33 & 9.38 & 9.12 & Full democracy \\
\hline Ireland & 9.05 & 8 & 6 & 10.00 & 7.86 & 8.33 & 9.38 & 9.71 & Full democracy \\
\hline Netherlands & 8.96 & $9=$ & 7 & 9.58 & 9.29 & 8.33 & 8.75 & 8.82 & Full democracy \\
\hline Switzerland & 8.83 & 12 & 8 & 9.58 & 8.57 & 7.78 & 9.38 & 8.82 & Full democracy \\
\hline Luxembourg & 8.68 & 13 & 9 & 10.00 & 8.57 & 6.67 & 8.75 & 9.41 & Full democracy \\
\hline Germany & 8.67 & 14 & 10 & 9.58 & 8.21 & 8.33 & 8.13 & 9.12 & Full democracy \\
\hline United Kingdom & 8.54 & 16 & 11 & 10.00 & 7.50 & 8.89 & 7.50 & 8.82 & Full democracy \\
\hline Austria & 8.16 & $18=$ & 12 & 9.58 & 7.50 & 8.33 & 6.88 & 8.53 & Full democracy \\
\hline Spain & 8.12 & 22 & 13 & 9.58 & 7.14 & 7.22 & 8.13 & 8.53 & Full democracy \\
\hline France & 7.99 & 24 & 14 & 9.58 & 7.50 & 7.78 & 6.88 & 8.24 & Flawed democracy \\
\hline Portugal & 7.90 & 26 & 15 & 9.58 & 7.50 & 6.11 & 7.50 & 8.82 & Flawed democracy \\
\hline Italy & 7.74 & 29 & 16 & 9.58 & 6.43 & 7.22 & 7.50 & 7.94 & Flawed democracy \\
\hline Malta & 7.68 & 30 & 17 & 9.17 & 6.79 & 6.11 & 8.13 & 8.24 & Flawed democracy \\
\hline Cyprus & 7.56 & 34 & 18 & 9.17 & 5.36 & 7.22 & 7.50 & 8.53 & Flawed democracy \\
\hline Belgium & 7.51 & 36 & 19 & 9.58 & 7.86 & 5.00 & 6.88 & 8.24 & Flawed democracy \\
\hline Greece & 7.39 & 37 & 20 & 9.58 & 5.21 & 6.11 & 7.50 & 8.53 & Flawed democracy \\
\hline Turkey & 4.48 & 104 & 21 & 3.50 & 5.36 & 5.56 & 5.63 & 2.35 & Hybrid regime \\
\hline
\end{tabular}

Такі показники, як політична культура (political culture) та політична участь (political participation) у значній мірі різняться. Бельгія суттєво відстає від Швейцарії. Нагадаємо, що Бельгія починала процес федералізму як унітарна національна держава, що в результаті реформи суттєво ослабла на користь передачі повноважень на місцевий рівень. Низький рівень політичної культури та політичної участі свідчать про те, що у бельгійців зростає почуття ототожнення себе з будь-яким іншим суб'єктом субнаціонального рівня. До того ж рівень ідентифікації громадян Бельгії до національної держави (критерій політичної культури) з кожним роком спадає. Проблема низького рівня політичної поведінки є актуальною і для України. Це пов'язано, по-перше, з ментальністю українського народу, якому більше імпонує сильна державна влада, що бере на себе всі обов'язки щодо задоволення потреб громадян. По-друге, з фактичним не розумінням своєї причетності до територіальної громади і можливості у зв'язку з цим вирішувати питання місцевого значення. Значною мірою громадяни України ототожнюють себе з проживанням на відповідній адміністративно-територіальній одиниці. Відповідно ментально українці “прив'язують” себе до державних інституцій, і аж ніяк не до територіальної громади.

Висновки. Досвід Швейцарії та Бельгії для України, на перший погляд, виглядає нестандартним для вивчення та застосування. Адже ми звикли вважати, що це надто розвинені та надто ментально відмінні від нас країни. Але саме ці країни, завдяки реформі децентралізації, зробили значний прорив у своєму розвитку. Проблема в тому, що для таких країн, як Бельгія і Швейцарія процес децентралізації був логічним та послідовним. Суспільство вже давно дозріло до необхідного рівня політичної соціалізації, щоб якісно долучатися до процесу прийняття рішень на місцях і нести за це відповідальність. Їм вдалося створити систему комун або муніципалітетів, але реформа проводилася хвилями, причому настрій населення постійно змінювався, багато хто реформі опирався, і уряду 
доводилося до цього пристосовуватися, боротися з супротивниками змін. У цих країнах $є$ влада закону, у нас - ні, вони вже мали розвинені традиції демократії, а в нас вони, нажаль, слабкі.

Проаналізувавши досвід впровадження та наслідки реформи децентралізації в Швейцарії та Бельгії можна зробити декілька застережень для політичної еліти України, яка переживає процес трансформації політичної системи саме в цьому напрямку.

В умовах проведення військових дій на території Донецької та Луганської областей, анексії Криму, ослаблення централізації влади в результаті реформи децентралізації значно впливає на показники ефективністі та стабільності української політичної системи. Зарубіжний досвід підтверджує, що в цілому успішні в політичному, економічному, соціальному плані країни в процесі здійснення децентралізації влади мали великі проблеми ефективності системи. Тому Україні в умовах глибокої політичної, економічної і соціальної кризи цей фактор слід завчасно враховувати, щоб попередити можливі негативні наслідки при подальшому впровадженні реформи.

Ослаблення централізації влади в результаті децентралізації може спричинити зростання свавілля місцевих чиновників і зростання незадоволеності населення владою, включаючи центральну, яка буде не в змозі і нездатна захистити інтереси і права регіональних громад. Ситуація з Covid-19 демонструє це як ніяк виразно. Децентралізація може підсилити відцентрові тенденції через вкрай низький рівень відповідальності держави перед адміністративно-територіальними суб'єктами.

Тому ключовим завданням, яке повинно бути виконано при децентралізації: самоврядування повинно виходити від місцевої громади - села, міста, а не області. В Швейцарії сильна місцева влада добре працює і не поспішає відокремлюватися, якщо вся самостійність зосереджена не на рівні областей (регіонів), а нижче - на рівні громад. Якщо виключити цей базовий рівень і віддати права областям, а не селам і містам, то вийде феодалізація, середньовіччя з місцевими князьками в областях, конвертованих у виді регіональних політичних еліт, які з часом почнуть провокувати формування регіональних сецесійних процесів.

Відносно низький рівень політичної культури та участі в політичному житті Бельгії не став на заваді реформуванню адміністративно-територіального устрою країни, хоча і певна кореляція тут має місце. Це повинно стати прикладом для тих, хто не вірить в успіх української децентралізації, обумовлюючи це вищеназваними причинами. Тим не менш децентралізація не повинна бути самоціллю, потрібно будувати належну систему управління. Для України буде важко побудувати таку систему, орієнтовану на людину, без участі цих людей. Щоб пробудити енергію мас, в Україні потрібні дуже сильні і всепроникні стимули, а ризик пробудження контрреформізму дуже великий. При цьому як для оптимістів, так і песимістів розвиток демократії на місцях виглядає бажаною метою. Але навіть якщо стимулів до розвитку місцевого самоврядування сьогодні немає, вони цілком можуть виникнути в майбутньому.

Таким чином, децентралізація - це не розділення країни, це створення можливостей для розвитку міст, сіл, селищ, там де живуть люди в єдиній Україні. Це створення умов, де громади зможуть активно залучатися до процесу прийняття рішень, це вивільнення енергії мас для покращення свого життя та життя своєї громади, а не створення додаткового прошарку регіональних політичних еліт.

Але, як показує практика, у кожної країни повинна бути своя дорога до реформування свого адміністративно-територіального устрою. Не має єдиного шаблону або рецепту, який був би успішним для кожної країни. Ми обрали для порівняння дві країни Європи з розвинутими демократичними системами, але все, що вони можуть зробити для України - це не принести вирішення цісї проблеми, а поділитися своїм досвідом проведення реформи. Не можна повністю копіювати чужу модель успішного впровадження реформи. Треба зважати на українську політичну, соціальну та економічну реальність, специфіку законодавства, елементи демократичних традицій, суспільний консенсус тощо. I на основі даного комплексу із багатьох факторів підлаштовувати реформу під себе, методом проб і помилок корелювати реформу у процесі.

\section{Бібліографічний список / References:}

1. Limits of Good Governance in Developing Countries / Hirotsune Kimura, Suharko, Aser B. Javier, Ake Tangsupvattana (eds.). Gadjah Mada University Press (Indonesia), 2011. 570 p.

2. Church, C. and Dardanelli, P. (2005). The Dynamics of Confederalism and Federalism: Comparing Switzerland and the EU, Regional and Federal Studies, 15 (2), pp. 163-185.

3. Rodden J. Comparative Federalism and Decentralization: On Meaning and Measurement// Comparative Politics. 2004. URL: http://www.jstor.org/stable/4150172

4. Worldwide Governance Indicators). URL: http://info.worldbank.org/governance/wgi/index.aspx\#home

5. Fragile States Index. URL: https://fragilestatesindex.org/comparative-analysis/

6. Democracy index 2020 URL: https://www.eiu.com/n/campaigns/democracy-index-2020/ 
7. Cullen R. Adaptive Federalism in Belgium // UNSW Law Journal. 2013. №2. p. 21 - 5

8. Coolidge, W.A. B. (1911). Switzerland/History/Constitution, in Chisholm, H.(ed.) Encyclopedia Britannica, 26 (11th ed.). Cambridge University Press. p. 259

9. Daniel Cetrà. Belgium won't split after Sunday's elections, but it could take a step in that direction // The Conversation Journal. May 20, 2014 URL: https://heconversation.com/belgium-wont-split-after-sundays-electionsbut-it-could-take-a-step-in-that-direction-26938

10. Decentralization: A Sampling of Definitions Archived 2013-05-12 at the Wayback Machine, October 1999, pp. 1, 3-6. URL: https://web.archive.org/web/20130512081813/http://web.undp.org/evaluation/documents/ decentralization_working_report.PDF

Chaltseva O. M., Jasko O. G. Decentralization as a Factor of Public Administration Efficiency on the Example of Switzerland and Belgium

The influence of the process of decentralization on the efficiency of public administration is analyzed on the example of Switzerland and Belgium. On a retrospective basis, the role and place of the decentralized nature of authority are described, and the advantages and disadvantages of the decentralization process are examined. The case-study method was used to reveal differences in the nature of the impact of decentralization of public authorities on the democratization of different political system types. The method of comparative analysis of the dynamics of decentralization of democratic federal systems is used, including cross-temporal and longitudinal analysis and binary comparison. Countries for the comparative analysis were selected according to the principle of system similarity. As a result, the general and specific political characteristics of two models of decentralized state structures in Switzerland and Belgium were identified.

The decentralized nature of authority is an important principle of functioning of effective management, but the importance of decentralization is different within various theories of public administration. The explanatory mechanism of the importance of decentralization also differs. Thus, according to Good Governance, decentralization is a way to bring public authorities closer to the citizens, to eliminate the phenomenon of political alienation, and to activate political participation, since the instruments of direct democracy that have a correlation in the basic principles of Good Governance can function to the best extent in small local territorial units. Therefore, in accordance with the provisions of the key theories of public administration, decentralization can be a factor of effective governance, since it is one of the principles of democracy functioning.

Decentralization is not about dividing the country, it is about creating opportunities for the development of cities, villages, and settlements where people live in unified Ukraine. This is about creating conditions where the communities can be actively involved in the decision-making process, it is about the withdrawal of energy of masses for the improvement of their own life and the life of their community, and not about creating an additional layer of regional political elites.

Keywords: decentralization, federalism, public administration, democracy, local self-governance. 